Beata J. GAWRYSZEWSKA

\section{Social participation in spatial order creation and its connection with day-to-day landscape structure}

\section{Introduction}

Human is a part of the environment so he, together with the rest of natural factors, participates in shaping of landscapes' physiognomy. The nature creates landscapes of a specific structure. Human creates cultural landscapes by imitating those structures through exploiting natural resources. In this process he uses landscape forms, rhythm, colours, proportion etc. that he observed in the nature. However those forms are already transformed in relation to the original, subjected to individual interpretation. For in the process of perception human interprets phenomenons that allow the cognition of landscape. Perception is a complex and individualized process in which the environment, observer and observation (result) are related (Richling, Solon, 2002)

Through physical presence in a particular space human makes it subordinated to a specific and permanent scheme - the front is more important than the back, "mine" tops "someone else's". "Places" are building up on this kind of structure, and meanings of those places create specific genius loci. Place and spirit of the place have their boundaries often conditioned more by the rules of culture than by the rules of nature.

This article attempt is to describe the structure of everyday landscape that results from the way it's used in. There are private, common and public spaces in the everyday landscape; additionally there is the phenomenon of the borders between them and untransformed landscape. Everyday landscape is the landscape of the closest human's surrounding, where his everyday activities happen - in the perceptive layer (what man sees around him on everyday basis). Though the everyday space is an existential space in a functional layer (space where man lives his everyday life) (Wiśniewska, 2003).

\section{Border resulted from the perception of the closest landscape}

Hundertwasser used to claim that man has 5 skins - borders of overlapping spaces that ensure his existence in the world: body's skin, clothing (cultural skin), house, region (a city, a district) where he lives and at last - the Earth. Each of those skins describes his humanity on a different level. Chinese geomants claimed, that human body ends on the border of his garden. How can one outline an optimal location for a border of a garden or a garden interior that is used as an everyday space of existence?
The research on territorialism conducted by Jan Rylke, carried out on the users of open spaces and home gardens in Poland, set the minimal demanded distance between a person or a group of people and an other (uknown) person for 20 meters. For an European a minimal garden size, in which he feels well (assuming that the area of garden is a skin that surrounds a man) is about $300 \mathrm{~m}^{2}$. The smallest community gardens in Poland are of this size. Assuming that the established number $(20 \mathrm{~m})$ relates to the distance between people, it requires twice as large intervals, that is interiors of about $1250 \mathrm{~m}^{2}$. That kind of interior could be used by small groups of 2 to 12 people (so a small or large family) ${ }^{[1]}$ (Rylke, Gawryszewska, 2000).

As important as the size of the everyday space is, the issue of physiological sensing and perception of an interior, in which the observer is situated, increased by specification of walls (Żurawski, 2000).

Researches on structures of trees and shrubs, (which were carried out to specify an optimal distance between plants and the observer, comfortable for noticing details of shapes, foliage, structure of the crown and flowers) were used to analyse width of roads leading to entrances and flower beds that accompany those paths. (Rylke, Gawryszewska, 2000) The average with of this lane is $2 \mathrm{~m}$ to $3,5 \mathrm{~m}$. When considering herbaceous and perennial plants, one should remember that their flowers and foliage is not situated on the hight of the sight line (though that's a situation with flowers of shrubs and trees), but lower $0,1-0,3 \mathrm{~m}$ above ground. The width of maximum $5 \mathrm{~m}$ creates a good perspective, adequate view on blossoming plants growing on very low beds. ${ }^{[2]}$

The border of sharp vision constitutes an invisible border of an interior, which is created by the path leading to the house entrance. A person who walks on that way should take in only the path that he/she walks on, between two node points (entrance to a property and doors of a building). The path offers many eye-catching accents, such as colours of flowers, diversity of plants' shapes and heights or rhythm of forms. Elements of garden structure are formed not only in a perspective of function (in this case: width of a path that is necessary for comfortable walking or width of bed convenient for cultivation), comfort of perception is also taken into consideration (Gawryszewska, 2000).

Considering the above, it can be stated that borders, walls of a garden interior, can be constituted by perceptive borders i.e. invisible walls. However; there is a material element needed that creates a point around which the life in a garden interior concentrates element that sanctions it's function. Trees are such elements. Places created around a tree have been seen in home gardens since at least the 16 th century. ${ }^{[3]}$

\section{Uniqueness of form}

It has been noticed that an entrance to a house, a border between public and private space creates along with the entrance to a property an integral structure - pre-garden (front garden). Both of those points are functionally connected 
with a path, an approach to doors of a house. This path is accompanied by decorative elements.

In the case of the analysed objects (polish home gardens and community gardens) an entrance to a property was always decorative. In comparison, entrance in an English garden is tantamount to an exit from a building (although it's possible to find decorative entrances there from a pre-garden's side, but it's usually locked or rarely used, it's not an "official" entrance used by household members or guests).

It was standard in those gardens to have an arranged entrance to a property and a building (house) with pairs of sculptures, shrubs or flower bowls that were called "guardians". Their function is dual: first of all they inform about the entrance, secondly they increase it's prestige. What was also characteristic, was a setting for an entrance to a garden in a form of "rose arch", two rambling rose shrubs, planted on both sides of a gate and spread on a metal, arcade-like construction (2-2.2 metre-high).

Concentration of symmetric and rhythmic forms, rich in symbolic meanings, throughout the entrance space, shows that rhythm and symmetry, aesthetics of classical proportions, pay an important role in the space of garden and house, it also stresses out a symbolic passage in the everyday space. Rituals of passage and customs that were connected to them are universal and characteristic not only for European but also for Far Eastern cultures (Gawryszewska, 2004). .... We can find tracks of beauty of penetrating (filtering) in the most distant history of humankind. Penetration of a city wall is in gates of those walls, in battlements and gaps in towers, coats of arms, colourful pennants, sounds of trumpets. Penetrating through a friendly house is a porch, portico, portal, doors and windows, spaces between, peristyle for example. They reveal richness of beauty sources" (Molicki, 1987).

Composition of classical proportions and rhythms in front gardens: gates, portals, balustrades on balconies, fence spans, allow feeling the uniqueness of the surrounding space. It appears regardless of a social status or residents' wealth, by palaces as well as by peasant cottages.

In the European culture "settlement" is an optimal form of spatial existence. It consists of house in a garden (private domain), a neighbouring domain in a form of a common space of a street (road) and areas that belong to the community (marketplaces, squares and greens). There is a place for a spatial development (management) in this structure, that has its specific functions and meanings, but there's also space for spatial "undevelopment" ("unmenagement"). If there are some fragments of natural or semi natural landscapes left in a settlement structure, which proves the biological need to return to untransformed nature. What seems to be extremely important in this situation is the phenomenon of the "passage space" - semi-private and at the same time semi-public spaces, where the language of cultural meanings contained in the garden composition (rhythmical forms, decorations, colourful flowers, sacred symbols, shrines, and sculptures) expresses symbolic isolation and opening, dynamics between private and common domain. It is connected to physiognomically different forms, characteristic for anthropogenic landscapes and spaces less transformed or nearly natural.

\section{Structure}

While researching contemporary home gardens it was observed that in almost all of those gardens, three functional zones can be distinguished. What is characteristic about those zones is that the further they are located from the house the less intimate and safe they are considered. The observed zone division is connected to the changing distance from the house by an emotional programme and garden composition.

Our everyday space is also strongly connected to gardens and front spaces that we pass on our way, walking through the streets. Their role is representative. Borders, fences, gates and doors they have ritual functions (that's where one passes from an "ordinary" space to a house space, bringing guests). Composition of such a space is subdued to a representative function (Gawryszewska, 2001).

It's essential when it comes to multi-occupied housings and common spaces that are connected with it, where correct articulation of borders between common and private domain is extremely important. These structures exist there in vestigial forms and public and common spaces pay similar role in the life of the community there as house garden in the life of an individual or a family. The role of front garden yard, the

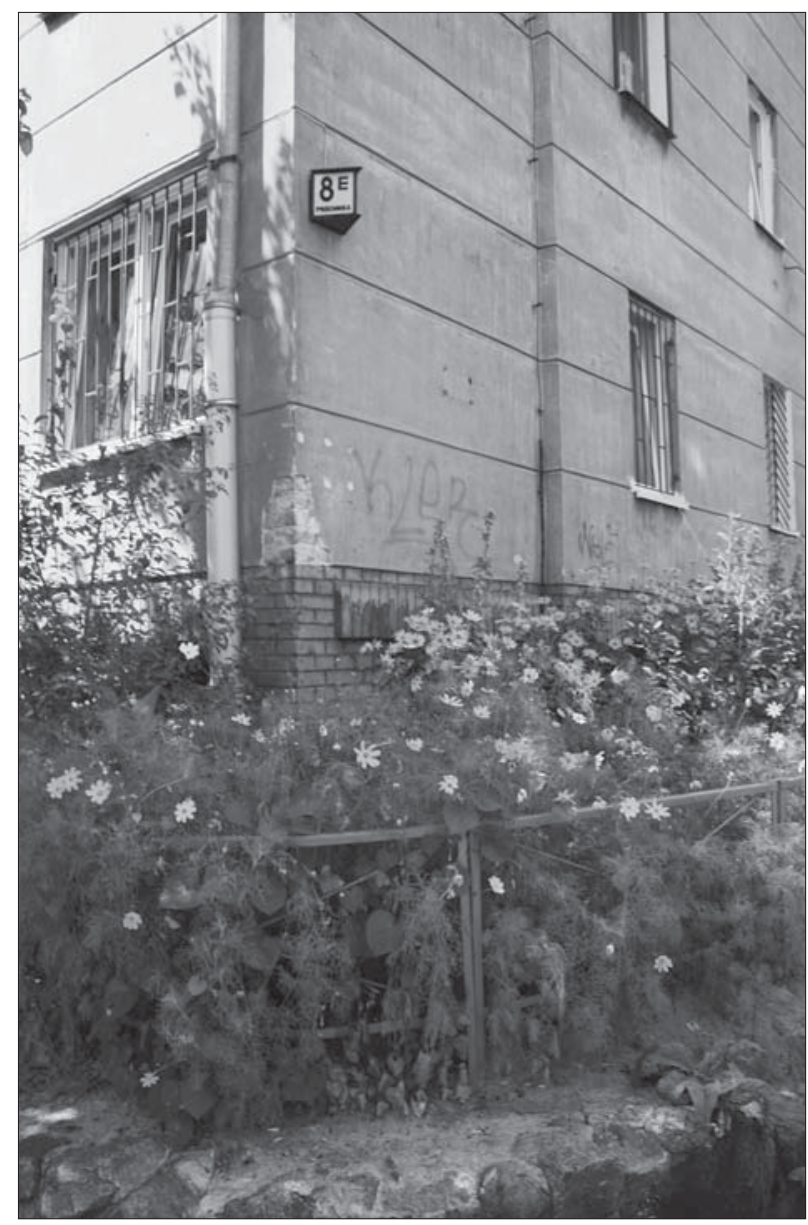

Figure 1: Substitute of frontgarden in Warsaw public housing development WSM Żoliborz (photo: Beata J. wryszewska). 
role of undeveloped zone - open spaces around the housing estate. ${ }^{[4]}$ Just like spaces in house gardens, common spaces are responsible for non-verbal communication inside a community, and also between neighbouring communities.

Cultural landscape holds a reminiscence of a natural landscape in a form of culmination of a structure of a settlement space with a semblance of a natural landscape - an undeveloped zone or developed extensively. It is artificiality created in urban landscape but in suburban or rural areas it is a natural continuation of open space areas, slightly transformed by its users (residents). It seems to be indispensable in a complete structure of settled space. If an environment is highly transformed already at the moment of gardens' establishing and (what goes along with it) desired spatial structures, then users create a semblance of a natural landscape by giving away to natural processes of succession, a fragment of the property that is the furthest from the house.

\section{The structure of a space - a consequence of natural process of site identity}

Structure of existential space is a consequence of a natural process of site identity and public space shaping and identification of their inhabitants with these sites. As a result of a process of identification with the site, system of private, social and public green spaces is being created. This structure has its image in green areas, created around places of living. Private space is marked out by private little gardens built under the windows of blocks, space of the settlement community - by green courtyards and parks, public space - by green alleys and public squares. City green areas designed in order like that, enable inhabitants to identify with place of dwelling, than improving sense of security and image of the scenery, provided its is crated with participation of them (Gawryszewska, 2005). Interesting, that polish famous theoretic of social architecture, Barbara Brukalska, who worked in 30-ties of XX century, when social idea of Chart of Athens was popularised, recommended structure of municipal greens like that. It should guaranteed comfort of dwelling and sense of freedom (Brukalska, 2006). The local community have to involve into project on every level from its planning to implementation. Participation of the local leaders in the program activated inhabitant. It also integrated community by bringing it back feeling of control over space and life, self-reword and proud of its neighborhood. Although, the role of program coordinator should be limited for advancements leading program and reinforcement of position of local leader, so the majority of decisions remained in management of community (Dobb, 1992).

Structure of the existential space allows not only attaches communities to their housing estates, but also to historical cultural landscape. They also help the local communities to identify themselves not only with local housing estate landscape but also with monumental landscape within which the new housing estates were built. Identification with the site, used this way, furthers not only standard of inhabited space but also monumental landscape promotion which leads to its revitalization.

\section{Social issues and municipal greenery in a space revitalisation process}

The active participation of local community is a key factor for long-term changes in landscape architecture. Christopher Alexander presented the vision of the participating architecture in which creation users take part actively. However, we have to remember that any attempt of mobilization of local community for taking the initiative is impossible without even basic identity of place represented among the community members. Thus, sense of identity of the place affects directly appearance of the place itself (Alexander et al., 1977).

Ames (1980) claimed that success of urban tree-planting programs depended more on level on local community involvement than on biological factors of tree survival. By engaging people into process of creation of their existential space we are giving them the opportunity to identify themselves with the place as well as we make them responsible for it. Thus, the inner gardens might be fundamental for establishing and restoring the social ties. Thanks to greenery we can draw the line connecting development and urbanization of the life space with the indissoluble bounds of human beings with nature.

Social participation in landscape order creation, realised and done in proper way should consist of:

1. Participation in the process of identification of the local needs and landscape values; leaded in the first phase of the local area management;

2. Participation in the order of space creation process - common work for design and realization;

3. Participation in space functioning process - deciding of public affairs in the space and about the ways of use the space.

\section{First example. Idea of Warsaw Royal Promenade - basis on a structure of an existential space}

The history of the Palace and Park in Wilanów began in 1677, when this terrain became the property of King John Sobieski III. Military successes and an increase of the importance of royalty in the coming years had a huge influence on expanding the initial project. Main construction works were conducted in the years 1677-1696. After completion, the building comprised of elements of a nobility house, an Italian garden villa and a French palace in the style of Louis XIV. After the death of the King, the Palace became the property of his sons, and in 1720 , a run down property was purchased by one of the wealthiest women in Poland of those days - Elizabeth Sieniawska. In 1730, the Palace, for three years, was owned by king August II the Strong, who made considerable changes in the residence, particularly as far as the internal décor is concerned.

In the middle of 18th century, the Wilanów property was inherited by the daughter of Czartoryski, wife of a field marshal, Izabela Lubomirska, during whose reign, Wilanów started shining with its previous glory. Sixty nine years later, the Duchess gave Wilanów to her daughter and her husband, 
Stanislaw Kostka Potocki. One of the first museums in Poland was opened in the Wilanów Palace, in 1805 (Museum Palace Wilanów, 2005). As a wonderful baroque royal residence it is one of the biggest and famous museums in Poland. Wilanów needs promotion as all wonderful places as that one. Not only with regard to necessity of gaining money, but first of all improving identity with the place of people of Warsaw. An importance of the place should be much higher in their consciousness.

For 400 years, the Wilanów residence has been a centre which has influenced social and spatial order of areas localized to the south of Warsaw. Warsaw development and the meaning of the residence result housing concentration which can cause absorption of the residence by urban space (Rylke et al., 2007).

Now Museum Palace of Wilanów occupies 45 ha, but in XIXth, properties of Wilanów were more then 100 times bigger. Territorial possessions reached otherside embankment of Vistula River and occupied terrains of present Mazovian Natural and on the left-side of the Vistula nearly to present area of Warsaw Fryderyk Chopin Airport. It was wise, beautiful and useful landscape wholeness, with farms, fields, meadows, forests, factories and compositive dominants - churches, palaces and parks. These days there are municipal areas of course. Parts of them are wastelands, second part - public green open spaces and nature reserves. There are also spaces with old, degraded trade infrastructure. We can not forget of course about few important monumental places, which create real landscape values of southern Warsaw. There are historic monumental residences, owner of which was the same family Potocki, which rules all Wilanów properties in XIXth and terrains Public Horse Race Courses, now out of business and left. On the bigger part of old property now we have old housing estate of blocks and new developing areas. Those play main role in our idea.

But why promotion of monuments is so difficult in Poland, especially in Warsaw? It is doubtlessly connected with polish difficult past - II Word War and communistic period. People of Warsaw have changed almost completely; city was depopulated after the Warsaw Rising in 1944. Now most people of Warsaw are extraneous, who don't identify until now with the place they living. There almost wasn't tradition of participation in space developing and making decision about it. Difficulty in leading of participation programs are deepen by the communistic past of Poland with 'social actions', when people were pressed to physic work in parks and municipal green spaces. Thus revitalization programs

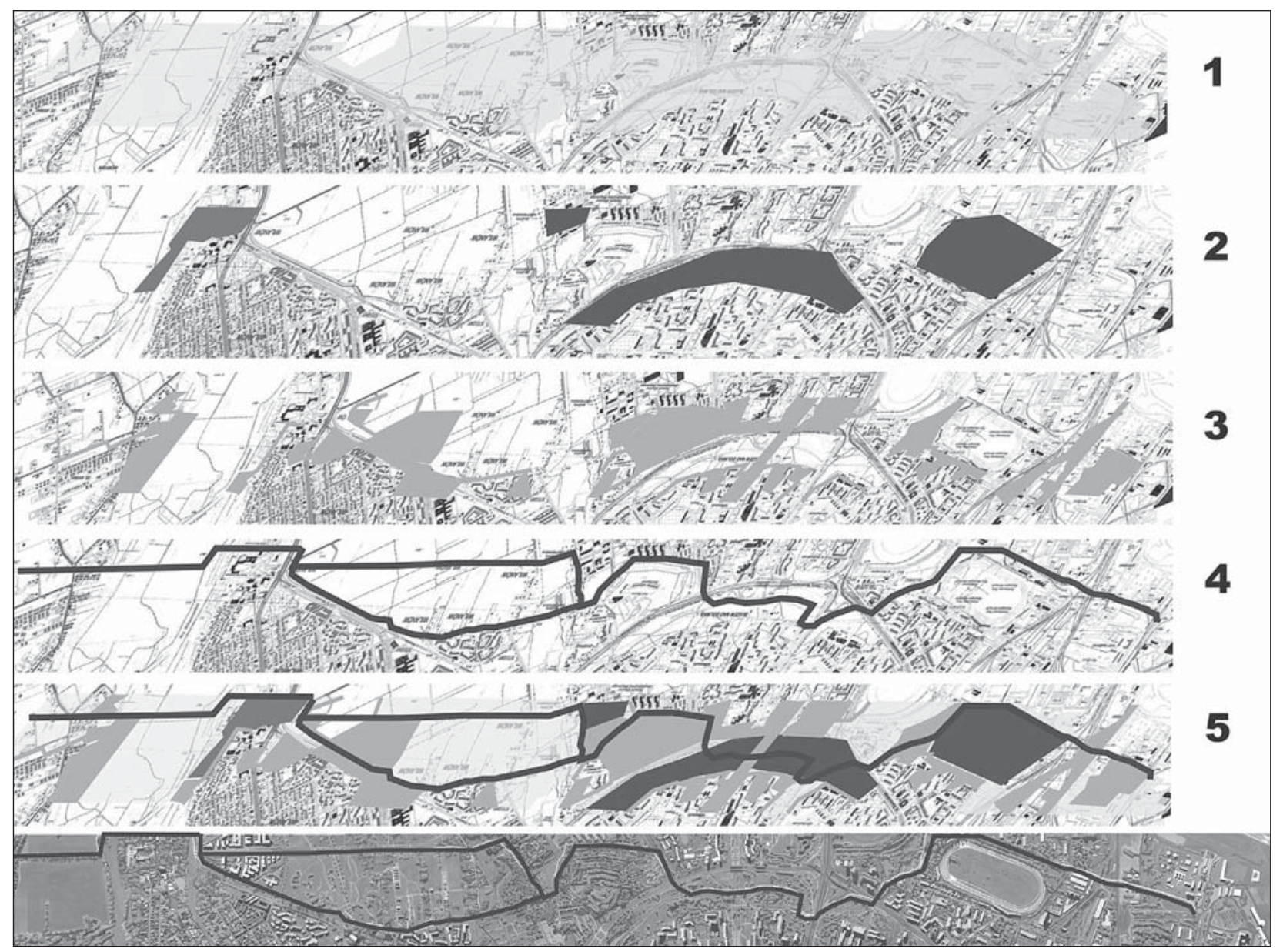

Figure 2: Warsaw Royal Promenade and its support by public greens: local parks for communities and public squares (by B. J. Gawryszewska): 1. Public open spaces (potential greens); 2. Existing parks and Museum Wilanów; 3 . Housing development line; 4. The promenade line; 5 . Model of the structure of Warsaw Royal Promenade green spaces with promenade line and axonometric view (by J. Rylke, M. Kaczyńska, T. Melnyk). 
of the cultural landscape must be leaded with background of dwelling places natural processes.

If we could retrieve relation between inhabitants and their space of living, and educe they will treat monuments of the cultural landscape as their own heritage, revitalization of the cultural landscape and identification with place and its monuments will be much effective (Gawryszewska, 2005).

We assume as following: nearly 60.000 people live on the area of old property, and they have no idea about it. They do not identify with the museum, which is far, do not identify even with their place of living, except the closest space near flats and houses. There is lack of public parks here, lack of good designed, useful public greens. Empty, old warehouses and stores, left destroyed factory buildings from 60-ties and 70-ties don't encourage to walks. All area is daily frozen by traffic jams, cause of lack of enough road and communication infrastructure

How to change this situation? Our team of designers - scientists from Section of Landscape Art, Warsaw University of life Sciences ${ }^{[5]}$ decided to change this threat into a basis supporting the monumental landscape and allowing for its effective revitalization. The Royal Promenade formal-spatial structure and course were designed based on existing and prevised social backup - inhabitants of housing estates and their existential space: public courtyards and parks as a continuous green system leading to public space of the Promenade.

An attempt to prevent this phenomenon is development of the Wilanów residence compositional axis as an urban axis of 11 kilometres length between Okęcie airport and Miedzeszyn embankment on the right side of the Vistula River. The axis, we proposed to create, has a character of park promenade which consists of avenues, squares and green spaces localized along the main road. Proposed urban green spaces system accompanying the promenade will consist of different scale objects: from squares, avenues with recreational program, parks, allotment gardens (or Permanent Gardens) to open areas.

\section{Second example. Educational and design workshops "We build the garden - world of our virtues". The method of school gardens and dwelling spaces design with the participation of local communities}

The workshops, which has lead since 2007 with high school youth aims to help identification with the place. We could reach it through reading and recognizing means of cultural landscape elements and looking for genius loci of the local landscape, then propagation of the method of shaping social space in the way of participation programs. Workshops were consisting of three phases, exemplifying three postulated phases of participation:

1. training in landscape values identification of dwelling space;

2. school garden designing;

3. realisation of the design.
Participants look for elements which express values in the near urban landscape. They give documentation - sketches, pictures, herbarium etc. Then they discuss about school community needs consider school garden, give them form and describe material, the elements have to be made with, take the model from documentation of the form and materials given earlier. Pupils create the model of the school garden, invited for cooperation landscape architecture students conceptual sketches. Then all the participants choose one of the elements of the project and build it.

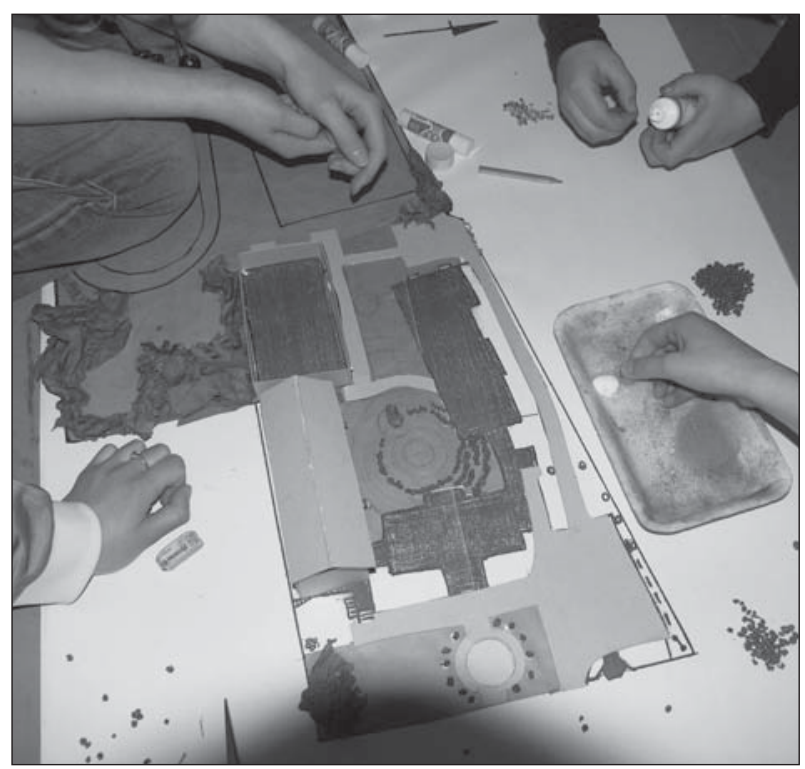

Figure 3: Collective work - designing of the school garden (photo: Beata J. Gawryszewska).

\section{Conclusion}

People in natural and spontaneous way aspire to create the structure described above in their existential space. All above can be summed up as follows:

- Space that we perceive is conditioned physiologically by our sight but also by culture and meanings that are assigned to it;

- In the process of space adaptation and appropriation, one identifies with it; building borders between private and public domain plays a deciding role. Borders are expressed through garden programme and architectural form of particular domains;

- Spatial borders contain important symbolic and cultural meanings (e.g. sacred symbols) that express meanings represented by individuals and communities that are involved in creation of the given landscape;

- Structure of day-to-day landscape contain an intensified forms characteristic for specific cultural spaces and the language of spatial meanings connected with social dialogue, but not a mixture of cultural and natural forms, (even though while building them one uses natural elements, e.g. plants).

Proper spatial structures, connected with system of the borders, being the succession of private, social and public 
domains with clear articulation of transient spaces create specific repertoire of forms and therefore dialog architecture spaces.

Specific of spatial order in Poland lies in its social values, and order tradition is tradition of social participation in architectonic canons shaping. Without social participation we can not talk about order - its proper shaping and mature supporting, which are conditions of order stability.

Examples of the structure, which was quoted in the text: Warsaw Housing Settlement designed by CIAM members B. and. S. Brukalski, workshops with high school pupils and Warsaw Royal Promenade Project by Section of Landscape Art, Warsaw University of Life Sciences team are also instruments which can shape social demand for recreational and cultural objects representing metropolitan character of Warsaw. As a long-term investment have to be shaped with participation of surrounding terrain inhabitants which conditions success of the investment (further use of the terrain as "defensible spaces" socially controlled which prevents devastation). These "natural", spontaneous, active participations of local communities are keys factors for long-term changes in landscape architecture and urban space order. By engaging people into process of creation of their existential space we are giving them the opportunity to identify themselves with the place as well as we make them responsible for it. Thus, the inner gardens might be fundamental for establishing and restoring the social ties. Thanks to greenery we can draw the line connecting development and urbanization of the life space with the indissoluble bounds of human beings with nature.

Dr. Beata J. Gawryszewska, Landscape Architect, Adjunct Professor Warsaw University of Life Sciences, Department of Horticulture and Landscape Architecture, Section of Landscape Art, Warsaw

E-mail: beata_gawryszewska@sggw.pl

\section{Notes}

[1] In two cases (in total amount 83) a plot was bigger, but only a relatively small part of the plot was assigned for a garden. In the first plot the remaining part of the grounds was used as a vegetable garden. The second piece of land (1,4 ha area) was divided by hedges to make few smaller gardens, 800-1200 square meters area. Such a size is considered as optimal and comfortable (not to small, not to big) for a mature, old English home gardens.
[2] The results of the research on this matter have shown that the distance for perception of flowers' structure comprise between 0,7-5,3 m.

[3] Similar interiors can be presently found. They can be seen in designs of famous authors such as Gertrude Jekyll, Herman Muthesius, Willy Lange.

[4] Based on the research carried out by the author in the space of WSM settlement in Warsaw.

[5] Jan Rylke, Beata J. Gawryszewska, Małgorzata Kaczyńska, Jeremi T. Królikowski, Tetyana Melnyk, Tomasz Turczynowicz, Joanna Dzięcioł.

\section{References}

Alexander, Ch., Ishikawa, S., and Silverstein, M. (1977) A pattern language: towns, buildings, construction. New York, Oxford University Press.

Ames, R. G. (1980) The sociology of urban tree planting. J. Arboricult, 6(5), pp. 120-123.

Brukalska, B. (2006) Zasady społeczne projektowania osiedli mieszkaniowych. Warszawa, Ideografia.

Dobb, E. (1992) Cultivating nature. The Sciences, Jan./Feb., pp. 44-50

Gawryszewska, B. (2000) Badania nad strukturą współczesnych ogrodów rodzinnych, in: Rylke, J. (ed.) Przyroda i miasto III, pp. 121-139. Warszawa, SGGW.

Gawryszewska, B. (2001) Struktura współczesnego ogrodu rodzinnego. Ph. D. Thesis. Warszawa, Warsaw University of Life Sciences, Departament of Horticulture and Landscape Architecture.

Gawryszewska, B. J. (2004) Estetyka przestrzeni wejściowej domu i ogrodu na przykładzie przestrzeni egzystencjalnej w Europie i Azji, in:Wilkoszewska, K. (ed.) Transestetyka. Estetyki kultur pozaeuropejskich, pp. 437-446. Kraków, Uniwersytet Jagielloński, Zakład Estetyki, Wydział Filozoficzny.

Gawryszewska, B. J. (2005) Uczestnictwo społeczne w kształtowaniu ładu przestrzeni i jego zwiq̨zek ze strukturą krajobrazu codziennego, in: Drapella -Hermansdorfer A., and Cebrat, K. (eds.) Oblicza równowagi. Aspects of equilibrium, pp. 240-247. Wrocław, Oficyna Wydawnicza Politechniki Wrocławskiej, Studia i materiały Wydziału Architektury Politechniki Wrocławskiej.

Molicki, W. J. (1987) Geneza piękna w architekturze. Manuscript. Richling, A., and Solon, J. (2002) Ekologia krajobrazu. Warszawa, PWN

Rylke, J., and Gawryszewska, B. (1999) Perception of the structure and habit of trees and shrubs. Annals of Warsaw Agricultural University, Horticulture (Landscape Architecture), 20, pp. 91-100

Rylke, J., Gawryszewska, B. J., Kaczyńska, M., Królikowski, J. T., Melnyk, T., Turczynowicz, T., and Dzięcioł, J. (2007) Idea promenady, in: Rylke, J. (ed.) Przyroda i Miasto X, pp. 214-231. Warszawa, SGGW.

Wiśniewska, W. (2003) Krajobrazy codzienne. Zeszyty Naukowe, 903(308), Politechnika Łódzka.

Żurawski, W. (1992) Przestrzeń i rzeczywistość. Kraków, Teka Komisji Urbanistyki i Architektury TXXI. 